\title{
SEISMIC VULNERABILITY OF HERITAGE CHURCHES IN QUÉBEC: THE NÉO-ROMAN TYPOLOGY
}

\author{
G. SFERRAZZA PAPA ${ }^{1 *}$, M-J. NOLLET ${ }^{2}$ AND M.A. PARISI ${ }^{3}$ \\ ${ }^{1}$ Politecnico di Milano, Dept. Architecture, Built Environment and Construction Engineering \\ piazza Leonardo Da Vinci, 32, 20133 Milano, Italy \\ e-mail: gessica.sferrazza@polimi.it (*corresponding author) \\ ${ }^{2}$ École de Technologie Supérieure, Department of Construction Engineering, \\ 1100 Notre-Dame St W, Montréal, QC H3C 1K3, Canada \\ e-mail: Marie-Jose.Nollet@etsmtl.ca \\ ${ }^{3}$ Politecnico di Milano, Dept. Architecture, Built Environment and Construction Engineering \\ piazza Leonardo Da Vinci, 32, 20133 Milano, Italy \\ e-mail: maria.parisi@polimi.it
}

Keywords: seismic vulnerability assessment, masonry churches, Néo-Roman typology, Québec

\begin{abstract}
Several seismic events have demonstrated the vulnerability of masonry churches. The long seismic history of the Italian territory has provided materials to observe and to study the structural performance of churches. Since the 1976 Friuli earthquake many studies have contributed to the definition of specific damage and vulnerability assessment methods for churches, based on the identification of macro-elements and kinematic mechanisms. In this context, the paper presents the application of a vulnerability assessment methodology developed and currently applied in Italy to a case study representative of the néo-roman church typology in Montreal, Québec. The study is part of a collaborative project between Politecnico di Milano and École de Technologie Supérieure of Montreal. The relevance of such a study derives from the moderate seismicity of Montreal associated to a high density of churches. Starting from a previous inventory of 108 churches in Montreal Island, the Néo-roman church typology was selected to be investigated. Specificities of this typology are the position of the bell tower in the middle of the façade and the interaction between the timber structure and masonry walls. This combination between the façade and bell tower macro-elements requires to reconsider the mechanisms associated to these elements in the original reference method. A detailed survey of the roof and bell tower timber structures of a néo-roman church was done, and a three-dimensional numerical model was developed for a better understanding of this type of structure. Modal analysis of a global model was then carried out and the first results of the modal shapes discussed.
\end{abstract}




\section{INTRODUCTION}

Churches are distinctive features of the urban and landscape scenarios. In seismic prone areas, their existence is frequently put at risk: unreinforced masonry churches have shown worldwide their seismic vulnerability [e.g. 1-4], due to their proper characteristics such as the presence of tall and little restrained walls of the nave, arches and vaults, large openings, and overhanging elements (e.g. gables, bell towers, pinnacles, statues...). Damage mainly occurs with recurring patterns in the different elements that compose the church, or macro-elements. Crack lines separate masonry blocks that eventually may develop a kinematic chain bringing to local collapse. Several decades of earthquakes and damage observations have brought to define for churches the most frequent damage -or limit- mechanisms [e.g. 5]. At the actual state of knowledge, an abacus of 28 such mechanisms has been developed in Italy, where it constitutes a reference for damage recognition and seismic vulnerability assessment campaigns [6,7]. The literature provides several examples of applications of this methodology, especially in damage surveys in the major earthquakes that arrived in the last decades, as L'Aquila (2009) [8,9], Emilia-Lombardy (2012) [10], and Central Italy (2016) $[11,12]$.

In 2018-2019, a collaborative research project between Politecnico di Milano and École de Technologie Supérieure in Montreal started, in order to test the applicability of the Italian seismic vulnerability assessment methodology to the churches of Québec. The basic question was to detect possible local construction characteristics that could require modifications of the

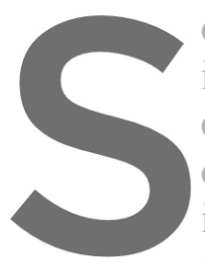
original procedure or island of Montreal had concerned is high even of buildings and the presence of several un inventory of 108 churches, for a selected sub out possible territoriat specificittes, intended as

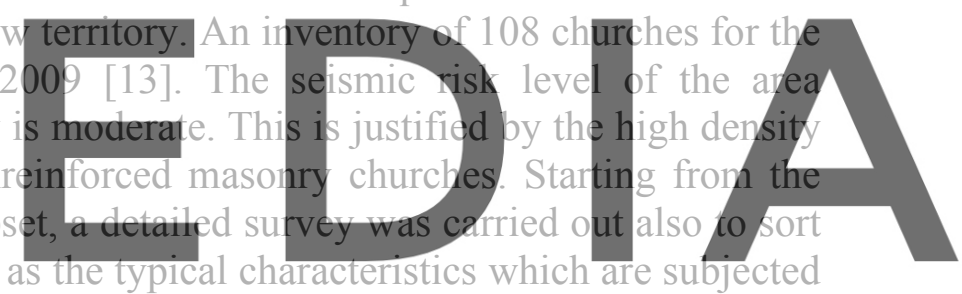
to significant changes from one territory to another [14]. Four principal typologies were

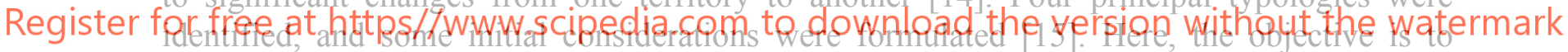

present results from a case study for the Néo-roman typology, also pointing out some difficuities in applying the Italian methodology to churches from this territory and the need for its updating with local characteristics.

\section{SEISMIC VULNERABILITY OF CHURCHES}

In Italy, the long seismic history and the collection of damage data after each earthquake since the Friuli earthquake of 1976 have provided a large amount of material for the study of the seismic damage and vulnerability assessment. Since the first steps moved in 1994 by Doglioni et al. [5], 28 possible failure mechanisms have been identified as the most recurrent in the Italian churches. This set is today a reference for two principal actions of assessment, that is:

- Damage assessment after an earthquake. In Italy such procedure was made official in 2006 and a specific form for damage survey of churches was issued [6].

- Rapid vulnerability assessment, in a prevention perspective. Possible initial damage, presence or absence of seismic protection devices, unfavorable conditions are pointed out and an evaluation of the vulnerability level of the asset is expressed. A detailed 
procedure is recommended by the Ministry of Cultural Heritage (MiBACT) [7].

In both cases, the assessment procedure is qualitative, and the result based on suitable reference scales. The basic assumption is that the masonry quality is sufficiently high to form monolithic blocks defined by fracture lines, acting as rotation hinges [16, 17]. When structural verification is required, limit equilibrium analysis may be performed for out-of-plane mechanisms, yielding the corresponding lateral force level.

The method of damage mechanisms is supported by extensive observational data, but it has been verified as well by more sophisticated models and analyses. Finite element models, usually requiring significant computational effort, may be adopted to follow the global behavior and the evolution of damage, often pointing out local damage situations that may be amenable to mechanisms. [i.e.18]. Where the global model evidences a local damage concentration, detailed local models may be performed defining suitable boundary conditions. This is often the case of the façade macro-element, highly subjected to damage and extensively investigated [i.e. 19].

\section{SEISMICITY OF QUEBEC AND HISTORICAL DAMAGE TO CHURCHES}

The province of Québec, in the Eastern part of Canada, is characterized by a moderate seismic hazard, except for the Charlevoix area, considered the most seismically active region [20]. Among the three seismic zones of Québec, Montreal is located in the so-called Western

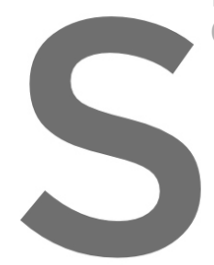
Québec Seismic Zone (figure
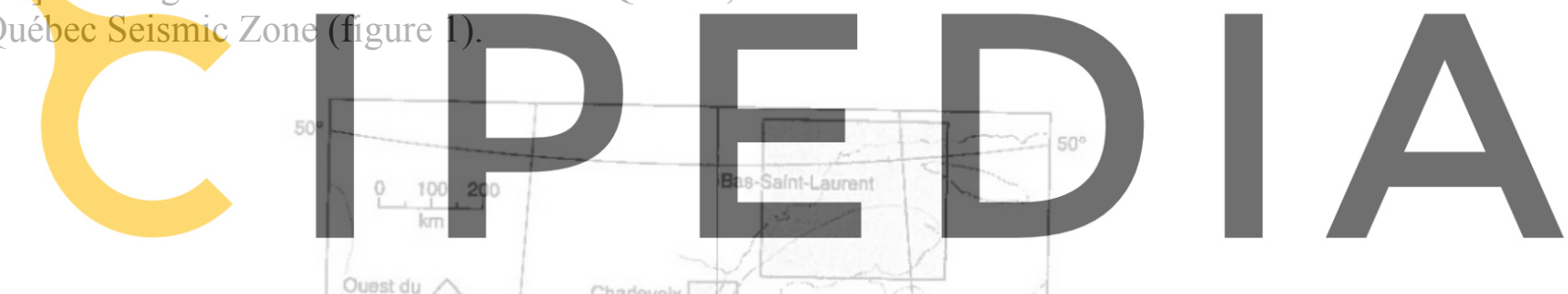

Register for free at https//www.scipedia.com to download the version without the watermark

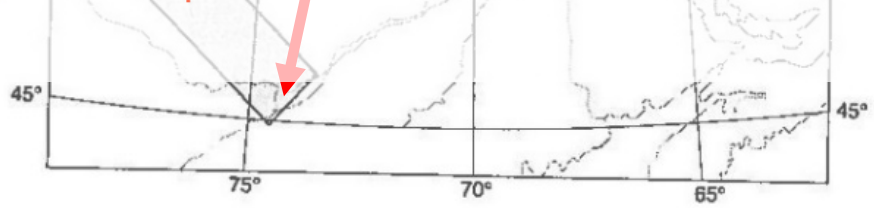

Figure 1 Principal seismic areas of east Canada: the west Québec (in the map 'Ouest du Québec'), Charlevoix, and Bas Saint Laurent. Montreal is in the west Québec zone (red arrow) [20].

The seismic hazard combined with the vulnerability of the churches evidences a considerable damage risk and points to the importance of a preventive action, including a seismic vulnerability analysis of this building typology. Indeed, just in the island of Montreal a total of 108 catholic churches have been inventoried in 2009 [13].

Table 1 provides an overview of the historical seismicity of the province. Major earthquakes, which struck Québec from the $17^{\text {th }}$ to the $21^{\text {st }}$ century, are listed in the table together with the damage suffered by churches and other unreinforced masonry structures. A territorial aspect to be considered in reading this table is the fact that before the end of the $17^{\text {th }}$ century most of the buildings were realized in timber. It is in consequence of the major fires occurred in 1682 
(Québec) and 1720 (Montreal) that masonry construction was enforced inside the fortification walls of the cities by Intendant Dupuy of Nouvelle France. Little photographic documentation is available on recent church damage compared to the extensive documentation collected in Italy after the systematic studies performed on the topic.

Table 1 Historical church damage in Québec [21]

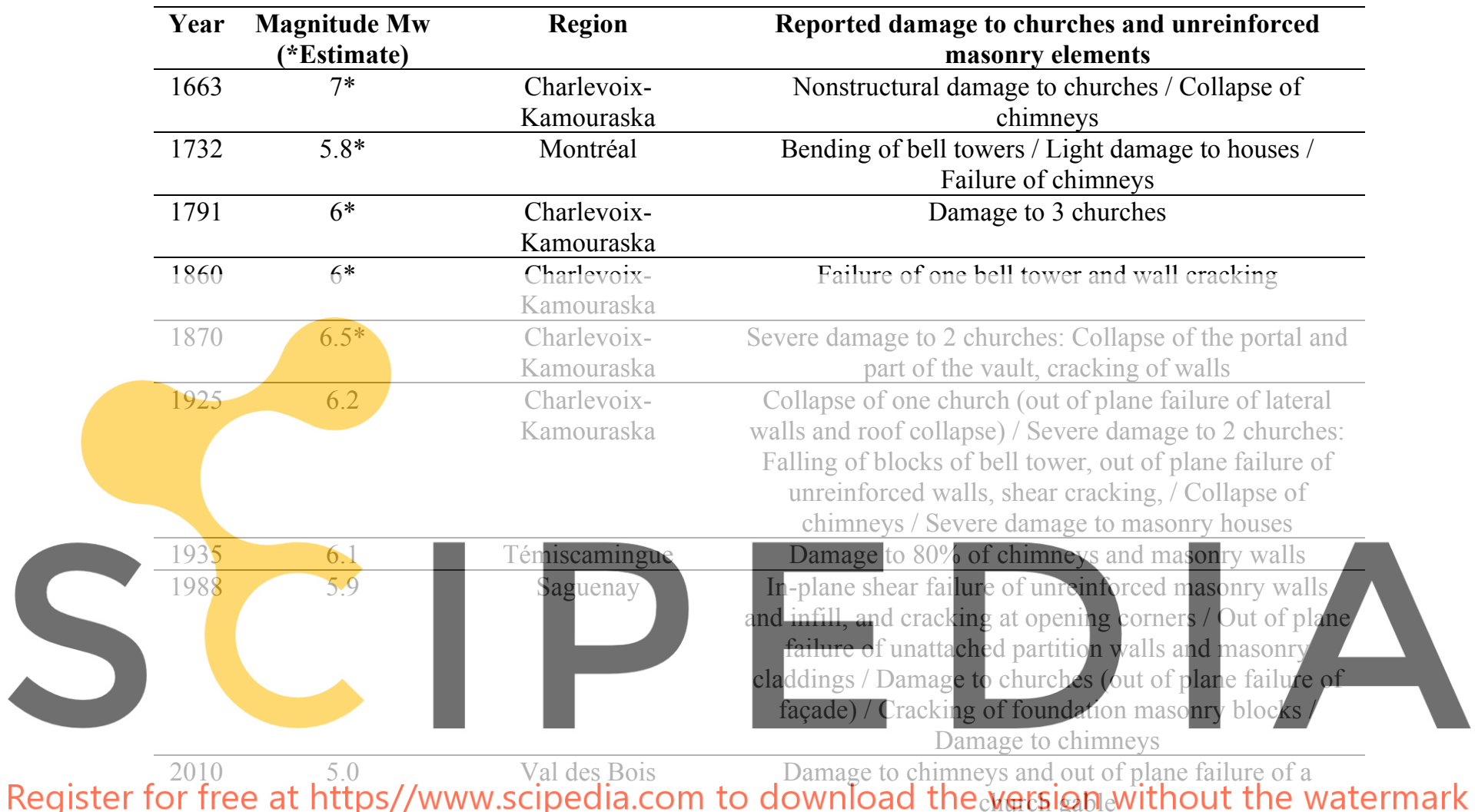

\section{CONSIDERATIONS ON THE IDENTIFIED TYPOLOGIES}

During a collaborative project between Politecnico di Milano and École de Technologie Superieure of Montreal some churches from the sample of 108 have been surveyed in detail, identifying among them four main typologies: the Baillargé (1790-1820), the Conefroy (from 1800), the Néo-roman (1880-1930), and the Italian baroque (second half of 1800) (figure 2).

Some initial considerations on the seismic vulnerability related to these typologies were expressed and detailed in [15] and are summarized here.

From a first screening of the visited churches it was possible to observe that among the inspected cases there is no use of seismic protection provisions and devices, such as tie rods. Only one case, the church of Notre Dame de Bon Secours, shows these elements. The church is classified as ' $\mathrm{A}$ ', according to the regional scale of value of protection and conservation elaborated by the Council of the Religious building stock of Québec [22]. A seismic vulnerability assessment of these churches was performed recurring to the rapid procedure based on the abacus of 28-mechanism outlined in section 2 [7]. It was observed that the direct applicability of the Italian methodology to the Québec churches is impractical, due to the 
territorial specificities of the churches. With respect to this condition, the category that showed to be more easily interpretable recurring to the Italian methodology is the so-called Italian baroque, for which the major vulnerability is associated to the gable macro-element. This portion of the façade, indeed, appears highly soaring and without any devices retaining it from overturning. For what concerns the other three identified typologies, the common aspect that stands out is the combined use of masonry and timber. The first is employed for the box structure of the church composed by the main walls and the second is used for the nave columns system, where a colonnade is present, the bell tower, and the roof structure. In all cases, the macro-elements supposedly most involved in case of earthquake are the façade, the bell tower and the lateral walls of the nave.

In the Baillargé typology, the façade interacts with two bell towers without being directly connected with the lateral walls of the nave, and at the same time creating a massive portion of structure with an atrium area. This configuration requires a deeper and specific investigation for a thorough understanding of the seismic response.

In the Conefroy typology, the façade is characterized by a hut shape with a series of openings. The bell tower does not interact with the roof structure, but it occupies an unusual position compared to the common Italian cases. It is located a step back from the façade plane. Understanding its structural behavior together with the transversal response of the nave requires a deeper analysis. These two aspects could lead to reconsider and possibly increment the 28 Italian mechanisms tailoring the set for Québec on the ground of these territorial specificities.
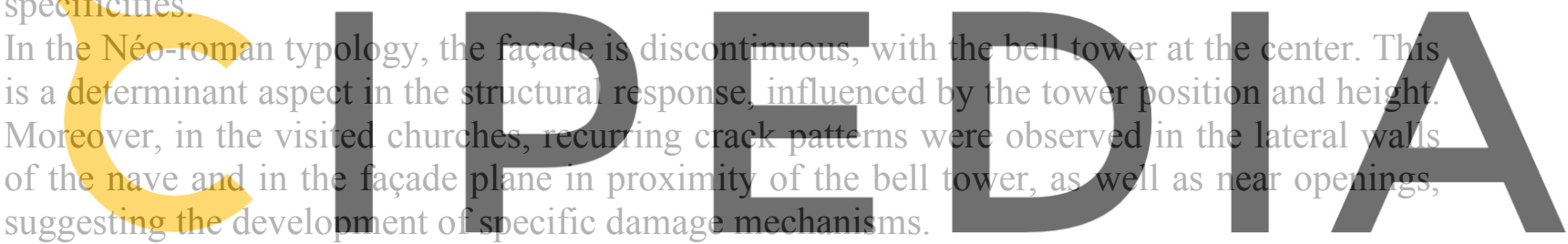

This typology was, thus, chosen as the first to be investigated in more detail.

Register for free at https//www.scipedia.com to download the version without the watermark

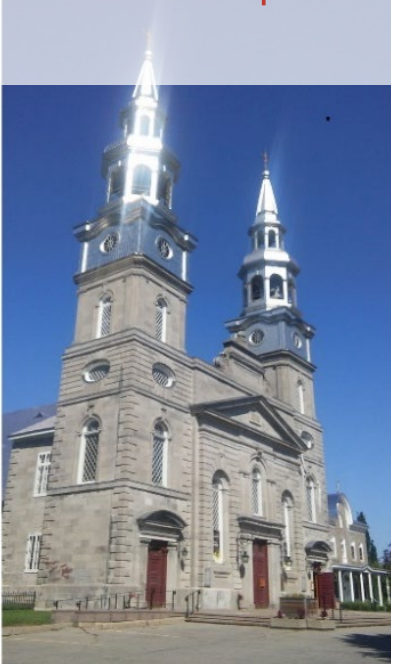

a.

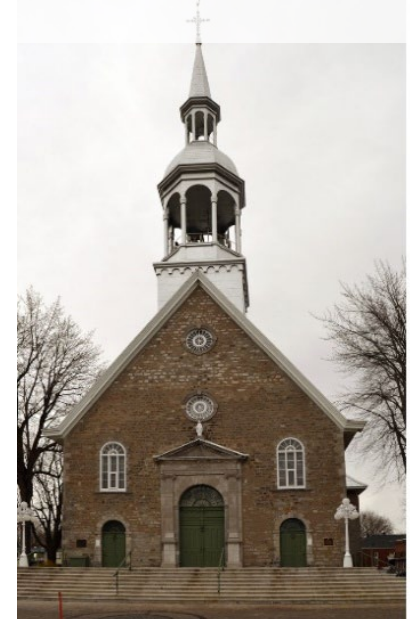

b.

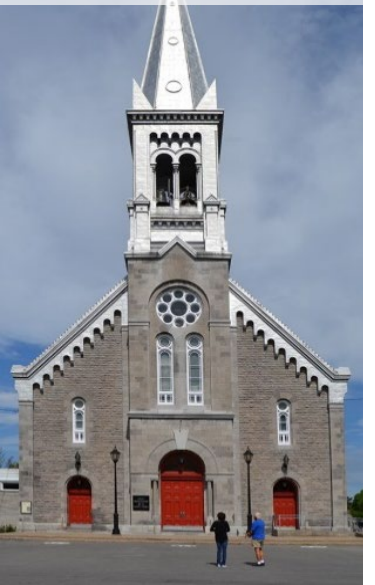

c.

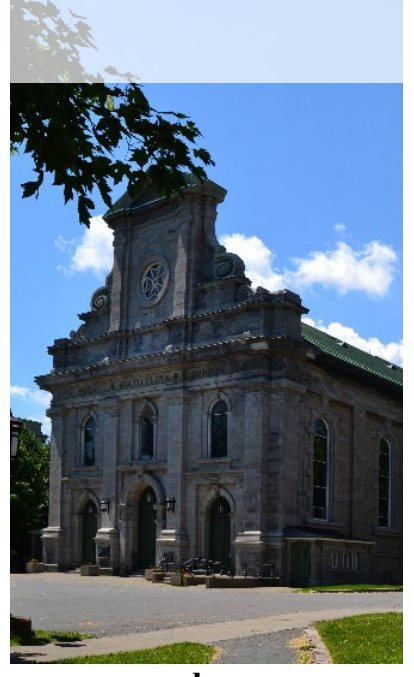

d.

Figure 2 Main typologies identified in the island of Montreal: a. the Baillargé; b. the Conefroy; c. the Néoroman; d. the Italian baroque. 


\section{THE NÉO-ROMAN TYPOLOGY: A CASE STUDY}

Direct application of the above-mentioned assessment procedure to the Néo-roman church typology appeared problematic because of the position of the bell tower, which is considered as a separate body in the original reference mechanisms. The mechanisms proposed for these two macro-elements by the abacus, reported in the following list and in fig.3, do not consider their interaction:

- Mechanism 1: overturning of the façade (figure 3a);

- Mechanism 2: overturning of the upper part of the façade (figure 3b);

- Mechanism 3: in-plane failure of the façade (figure 3c);

- Mechanism 27: failure of the bell tower along the height (figure 3d);

- Mechanism 28: failure of the upper portion of the bell tower (figure 3e).

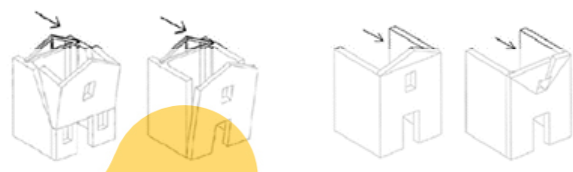

b.

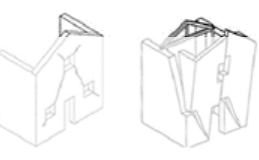

c.

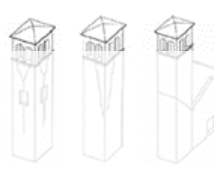

d.

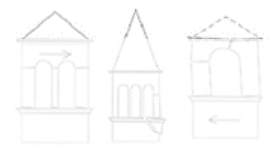

e.

Figure 3 Mechanisms associated to the façade and bell tower macro-elements: a. Mechanism 1; b. Mechanism 2; c. Mechanism 3; d. Mechanism 27; e. Mechanism 28.

The Néo-Roman church of St. Joseph des-Prairies in Montreal was chosen for a case study. The church dates bacik neighborhood in the no (figure 4), it confirms scenario. Indeed, Montrual was defined he city o
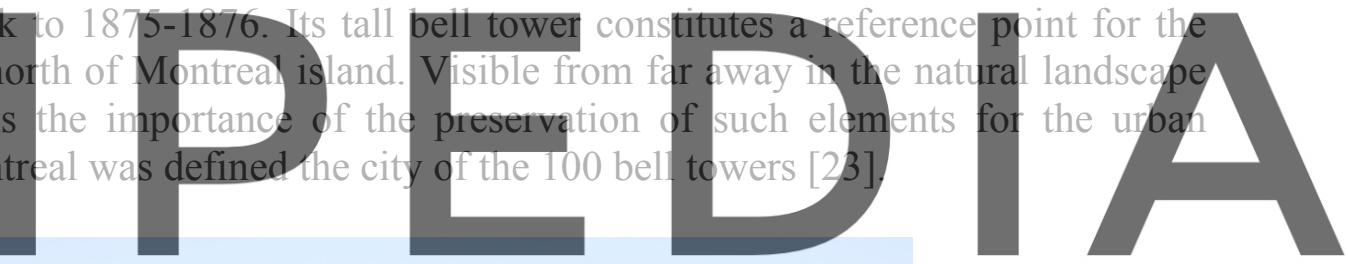

Register for free at https//www.scipedia.com to download the version without the watermark

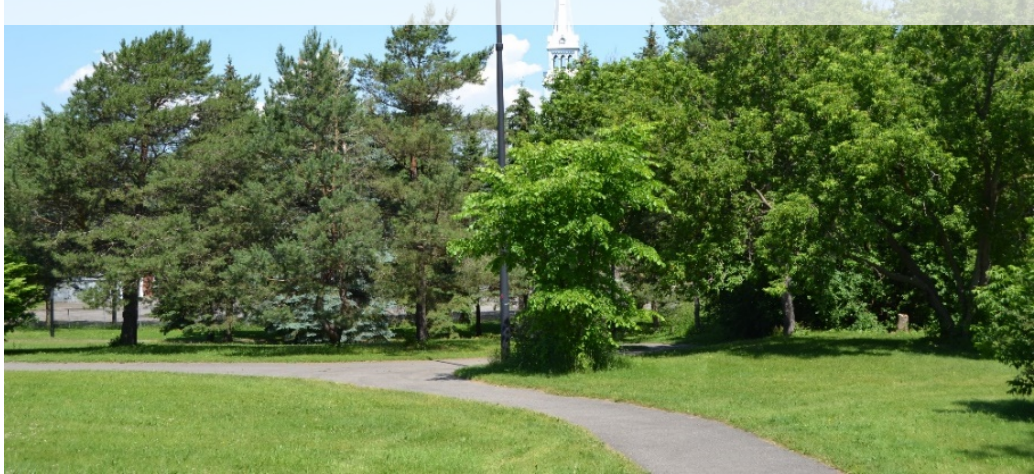

Figure 4 Bell tower of St. Joseph visible from far away in the landscape.

The main body of the church is isolated from the presbytery and it is composed of the nave and the apse, and in the back side, of the sacristy (figure 5). 


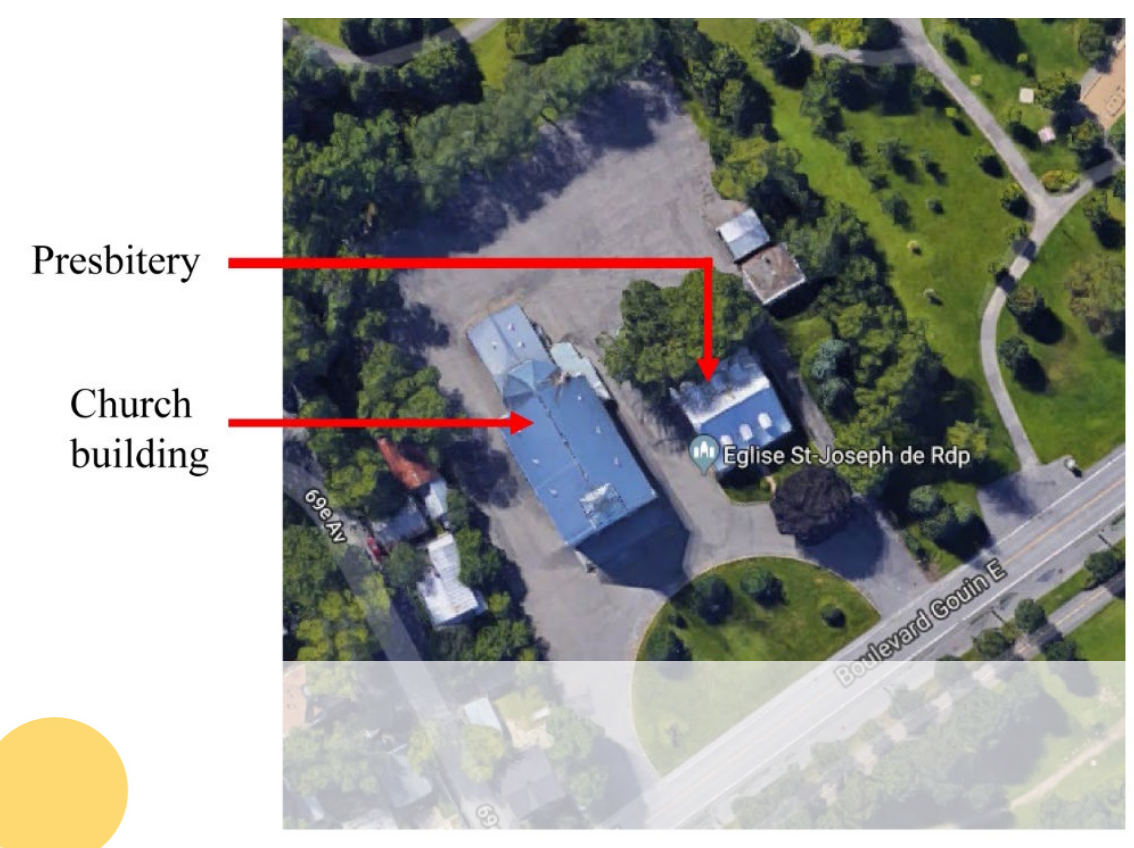

Figure 5 St. Joseph: the church and the presbitery

The façade of this church has a distinguishing aspect. The bell tower, which interrupts the hut shape of the façade at the middie, is flanked by a pair of buttresses (figure 6a). The curtain walls of the church are made of stone masonry. Multi-leaf walls are connected other through well-defined stone blocks (Figure 6b). This solution was frecuently the inspected churches and, therefore, it has been identified as a territorial specificity.

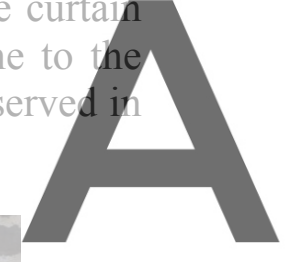

Register for free at https//www.scipedia.com to download the version without the watermark

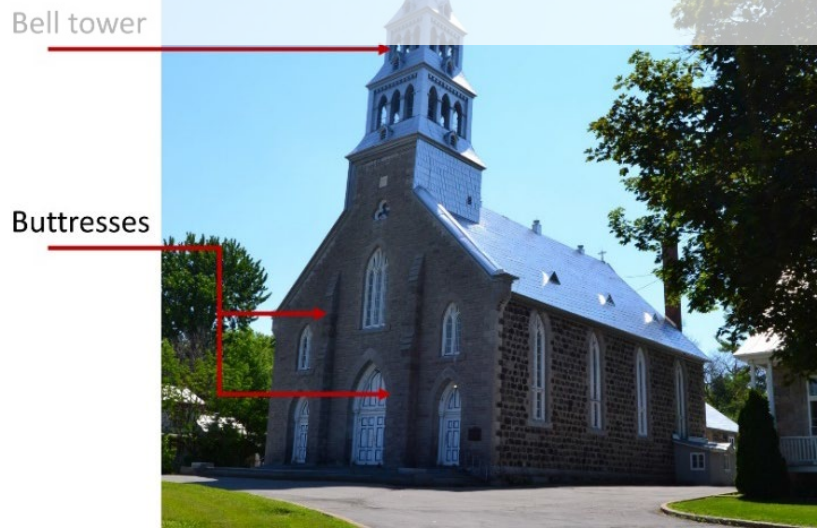

a.

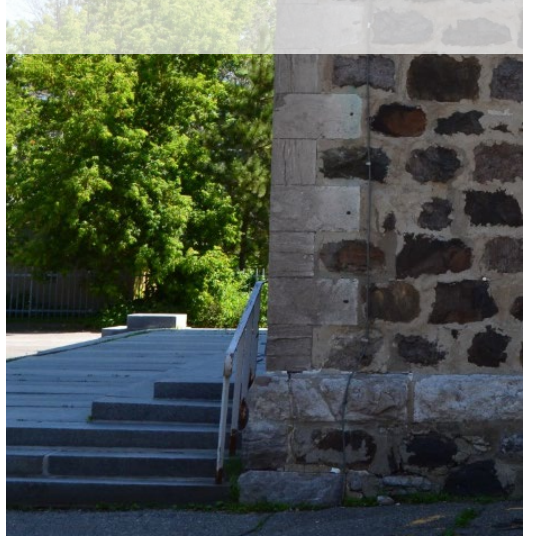

b.

Figure 6 The exterior of the church: a. The principal elevation; $\mathbf{b}$. The detail of interconnection between walls.

The church has three naves with a timber colonnade that, giving rhythm to the space of the 
nave, supports the roof structure together with the lateral walls of the nave (figure 7). An overhanging deck, called "jubé", hosting the choir and, as in most of the churches, the organ, characterizes the space of the church entrance.

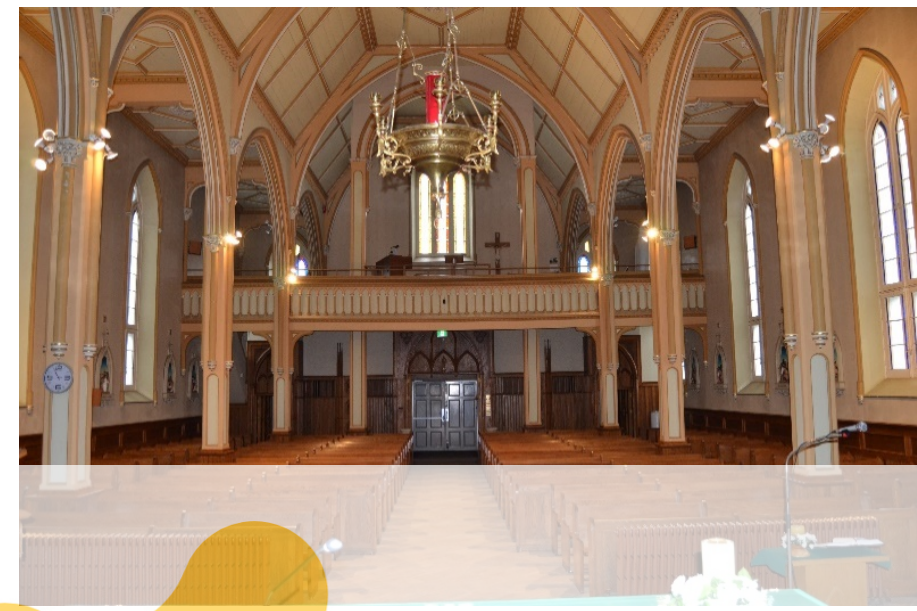

a.

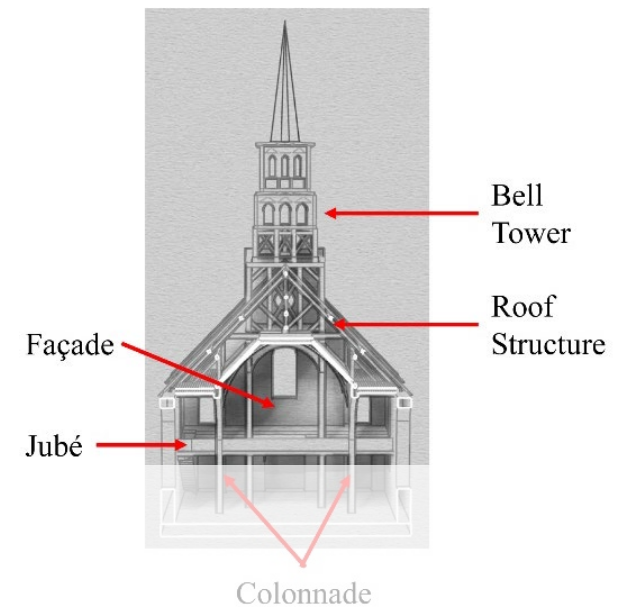

b.

Figure 7 The configuration of the structure of the church: a. Colonnade of the nave and jubé; $\mathbf{b}$. Transversal section of the church.

In order to interpret the structural behavior, also a detailed inspection of the roof and bell tower area was performed. This action vas a fundamental step to understand the complexity of the structure of roo brought to elaborate constituted the basis for the state of conservation and bell tower and the
complete tbree-dime
a finite element model. and between timber elements and masonry, and to detect the presence of existing cracks that,

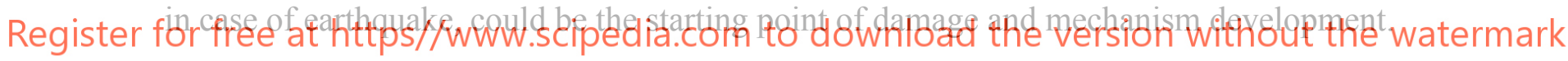

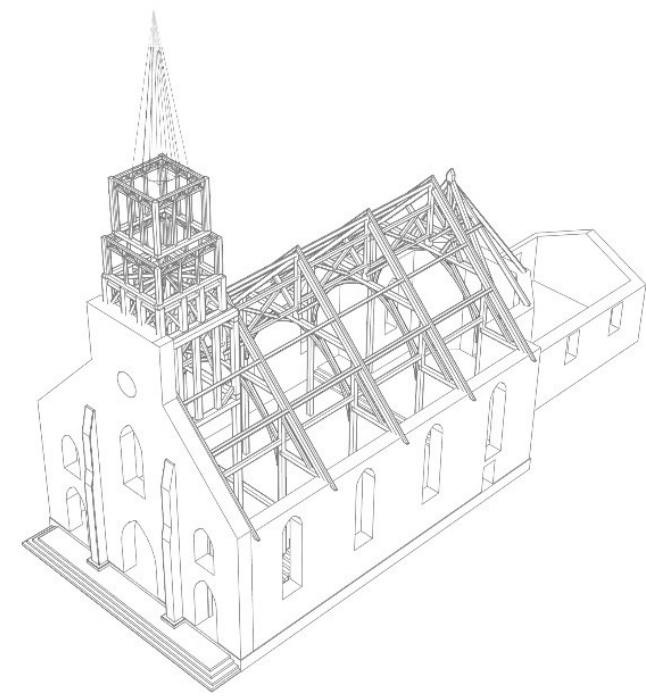

Figure 8 Three-dimensional geometrical model of St. Joseph. 


\subsection{Structural analysis}

A finite element model was elaborated in Abaqus [27] to investigate the global structural behavior of the church. A first stage of the study concerned the masonry structure, with the aim at understanding the role of the main structural elements on the response. At this step, linear analyses were implemented, while non-linear analyses were not performed due to the lack of extensive damage data, as it occurs in the Italian territory. Indeed, such comparison would allow the calibration of the results, considering them reliable. A mesh of over 36000 tetrahedral elements was developed, with two elements in the thickness of the walls (figure 9).

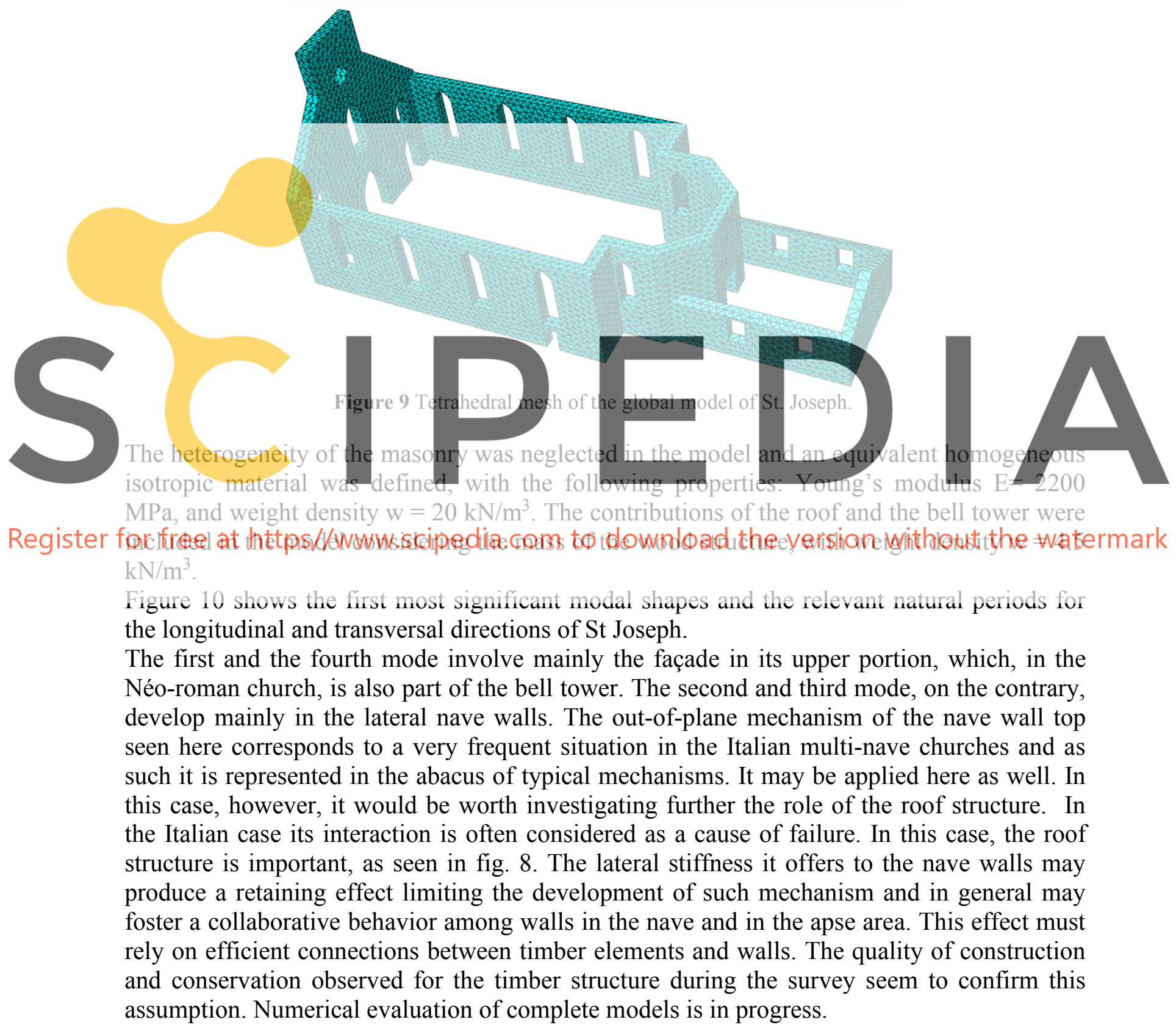


The main characteristics of this Néo-Roman church reside in the bell tower and the façade. Contrary to the assumption of interaction of the roof structure with the façade that is made very frequently in the Italian cases, often ascribing to roof pounding the damage produced at the tympanum top, the Canadian case has no connection between the two. The fundamental modal shape, as well as the third mode, recall what is probably the most frequent mechanism listed in the abacus, i.e. the bending failure of the façade top. The assumption of full connection of the façade with the nave walls in the numerical model is confirmed by the careful execution of the masonry at the corner as in fig. 6.b, which inhibits a full rotation of the façade limiting the mechanism to the upper part. The presence of the timber structure of the bell tower, which in this first phase has been considered only as applied mass, is under investigation to detail better the façade top mechanism, which appears as the dominating one for this church typology.

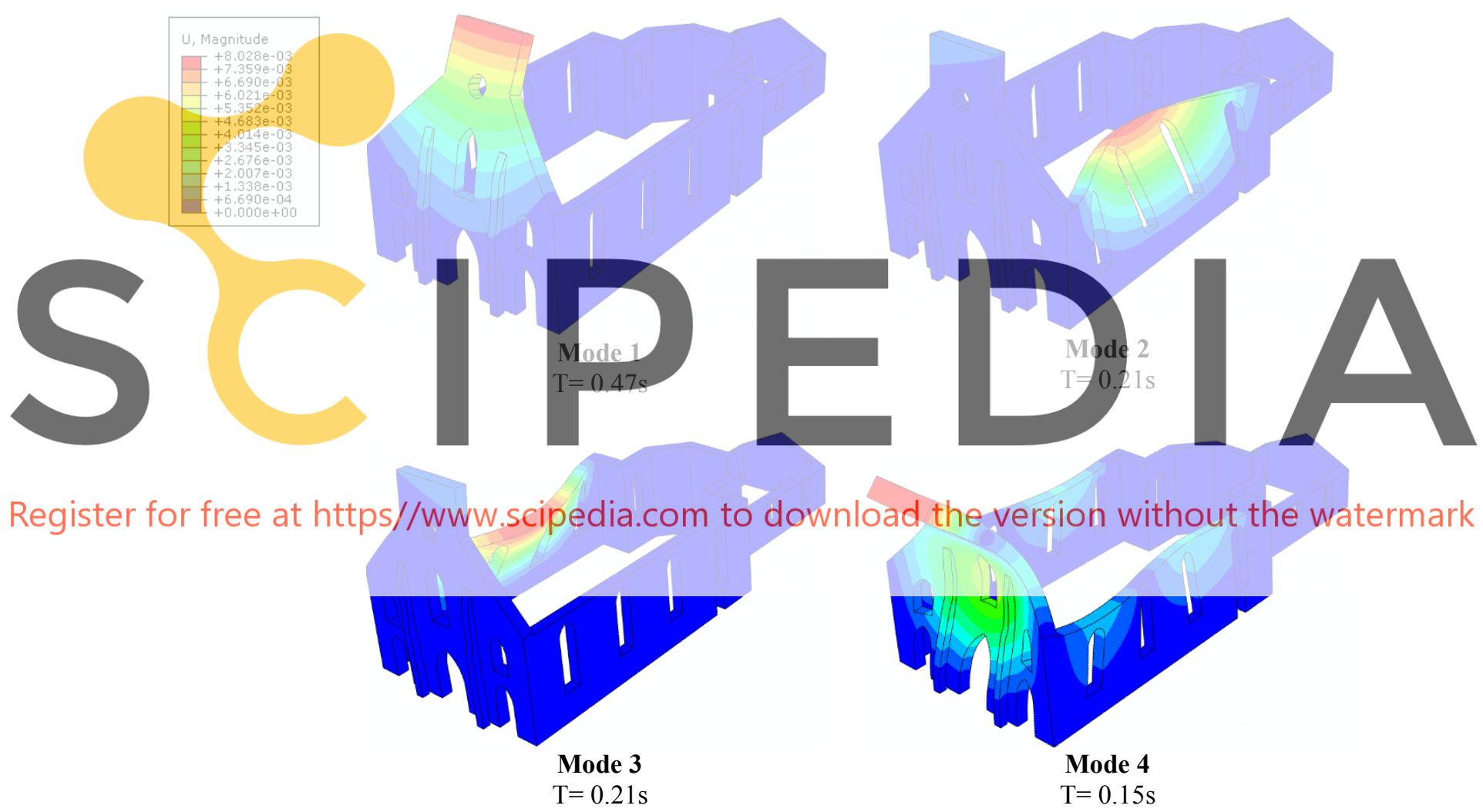

Figure 10 First modal shapes with the corresponding period

\section{CONCLUSIONS}

The seismic vulnerability of churches is a well-known problem in the preservation of cultural heritage. The seismic damage documented for the churches in Québec and their numerousness elicited studying the seismic behavior of one of the identified church 
typologies, the Néo-roman.

Starting from an assessment procedure developed for churches in Italy, a case study has given indication of local construction characteristics that influence the seismic behavior; this information may be used to increment the original reference damage mechanisms extending the procedure in order to its application in a different territory.

Additional analyses concerning the timber elements and their interaction with masonry as well as more advanced material behavior are in progress.

\section{Acknowledgements.}

The financial support provided to the first author by the Fonds de recherche du Québec Nature et technologies (FRQNT) for an International internship is gratefully acknowledged. The third author acknowledges partial support from the Reluis-DPC 2019-21 project. The authors also wish to thank all the persons in the Diocèse de Montréal and the parishes of the visited churches for their indefectible collaboration and their generosity in sharing their time and knowledge. The participation of Roxanne Carrier to this project as a visiting student in Politecnico di Milano from ETS is also greatly acknowledged.

\section{REFERENCES}

[1] D'Ayala, D. and Benzoni, G. (2012) Historic and traditional structures during the 2010 chile earthquake: Observations, codes, and conservation strategies. Earth Spectr 28 (S1): S425-51.

[2] Cancino, C. (2011) Damage assessment of historic earthen buildings after the August 15, 2007, Pisco, Peru earthquake. Getty Conservation Institute, Los Angeles.

[3] D’Ayala, D., C. Galasso, V. Putrino, D. Fanciullacci, P. Barucco, V. Fanciullacci, C. Bronzino, et al. (2016) Assessment of the multi-hazard vulnerability of priority cultural heritage structures in the Philippines. Proceedings of the $1^{\text {st }}$ International Conference on Natural Hazards and Infrastructure, Chania, Greece.

[4] Marotta A., Sorrentino L., Liberatore D., Ingham J. (2017) Vulnerability assessment of unreinforced masonry churches following the 2010-2011 Canterbury earthquake sequence. J Earthq Eng 21(6):912-934.

[5] Doglioni, F., Moretti, A., Petrini, V. (1994) Le chiese e il terremoto. Trieste, Lint.

[6] DC PCM-DPC MIBAC. 2006. Form of damage for churches. Form A. Available from http://www.beniculturali.it/mibac/multimedia/MiBAC/documents/1338454237471_alleg ato4.pdf (Accessed January 31, 2020).

[7] MiBACT (2011). Linee Guida per la Valutazione e Riduzione del Rischio Sismico del Patrimonio Culturale Allineate alle Nuove Norme Tecniche per le Costruzioni (D.M. 14 Gennaio 2008). Attachment C.

[8] Da Porto, F., Silva, B., Costa, C., and Modena, C. (2012) Macro-scale analysis of damage to churches after earthquake in Abruzzo (Italy) on April 6, 2009, J. Earth. Eng., 16, 739-758.

[9] Brandonisio, G., Lucibello, G., Mele, E., and De Luca, A. (2013) Damage and performance evaluation of masonry churches in the 2009 L'Aquila earthquake, Engineering Failure Analysis, 34, 693-714. 
[10] Sorrentino, L., Liberatore,L. Decanini, L. D., Liberatore, D. (2014) The performance of churches in the 2012 Emilia earthquakes, Bull Earthquake Eng 12: 2299-2331

[11] De Matteis, G., Zizi, M., and Corlito, V. (2017) Analisi preliminare degli effetti del terremoto del Centro Italia del 2016 sulle chiese a una navata. In ANIDIS XVII Convegno L'Ingegneria sismica in Italia, Pistoia, Italy, 17-21 September.

[12] Cescatti, E., Taffarel, S., Leggio, A., da Porto, F., and Modena, C. (2017) Macroscale damage assessment of URM churches after the 2016 earthquake sequence in Centre of Italy In: ANIDIS XVII Convegno L'Ingegneria sismica in Italia, Pistoia, Italy, 17-21 September.

[13] Youance, S. (2009) Évaluation de la vulnérabilité sismique des églises du Québec, ETS, Montreal.

[14] Sferrazza Papa, G. (2020) Seismic vulnerability of churches: a territorial knowledge approach, PhD Thesis, Politecnico di Milano, Milano.

[15] Sferrazza Papa, G., Parisi, M.A., Nollet, M-J. (2019) Seismic vulnerability of churches: the effect of context-related characteristics. In: ANIDIS XVIII L'Ingegneria sismica in Italia, Ascoli Piceno, Italy, 17-21 September.

[16] Lagomarsino, S. and Podestà, S. (2004a) Damage and vulnerability assessment of churches after the 2002 Molise, litaly, earthquake. Earth Spect 20 (S1): S271-83.

[17] Lagomarsino, S. and Podestà, S. (2004b) Seismic vulnerability of ancient churches: I. damage assessment and emergency planning. Earth Spect 20 (2): 377-94.

[18] Valente, M. and Milani, G. (2018) Seismic response and damage patterns of masonry churches: Seven case studies in Ferrara, Italy. Eng. Struct. 177 : 809-35.

[19] Casolo, S., S. Neumair, M. A. Parisi, and V. Petrini. 2000. Analysis of seismic damage patterns in old masonry church façades. Earth Spect 16 (4): 757-73.

[20] Adams, J. and Basham, P. (1989) The seismicity and seismotectonics of Canada East of the Cordillera. Geoscience Canada, Vol.16 (1).

[21] Nollet, M.-J., Abo El Ezz, A., and Nastev, M. (2013). Seismic risk assessment of unreinforced masonry buildings in Québec, In: 12th Canadian Masonry Symposium Vancouver, Bristish Columbia, June 2-5, 2013.

[22] Le Patrimoine religieux du Québec. Les églises de la deuxième moitié du XIXe siècle. Available from http://www.gdcr.umontreal.ca/patrimoine/connaissance/catholicisme/dossier4.html (Accessed January 31 2020).

[23] Québec's National Shrines. Montreal: The city of a hundred bell towers. Available from http://www.sanctuairesquebec.com/en/ (Accessed December, 28 2018).

[24] Parisi M A, Chesi C, Tardini C, Piazza M, (2008). Seismic vulnerability and preservation of timber roof structures. In: Proceedings SAHC08, Bath,UK, pp. 12531260.

[25] Chesi C, Parisi MA and Tardini C (2012) Inferring seismic behavior from morphohology in timber roofs, International Journal of Architectural Heritage, 6:100116.

[26] Parisi MA and Chesi C (2014) Seismic vulnerability of traditional buildings: the effect of roof-masonry walls interaction. In: 10th U.S. National Conference on Earthquake Engineering. Anchorage, Alaska, 21-25 July.

[27] Abaqus (2016) Theory manual, version 2016. 